\title{
Extracts of Oxalis triangularis shows broad spectrum antibacterial activity in acidic condition.
}

\author{
Yong-Gon Kim¹, Do-Gyu Ko ${ }^{1}$, Hyun-Suk Kim¹, Jung-Sup Kim ${ }^{2 *}$ \\ ${ }^{1}$ Namnyeong High School, Jeju, Republic of Korea \\ ${ }^{2}$ Faculty of Biotechnology, SARI, Jeju National University, Jeju, Republic of Korea
}

\begin{abstract}
Antimicrobial effects of various plants have been widely used to prevent diseases. Antibacterial activity in the extracts of Oxalis triangularis against five Gram-positive bacteria and three Gram-negative bacteria was investigated. The extracts of $O$. triangularis were tested the antibacterial activity against several Gram (+) and Gram (-) bacteria. The antibacterial activity was tested in the heat-treated extracts from leaves of $O$. triangularis as well as in the extracts of the various $\mathrm{pH}$ by $\mathrm{NaOH}$ addition. The extracts from leaves, stems, roots, and buds of $O$. triangularis showed broad spectrum antibacterial activity against all bacteria tested including Staphylococcus aureus, Bacillus cereus, Escherichia coli and Salmonella typhimurium. The heat-treated extracts from leaves of $O$. triangularis showed the similar antibacterial activity. However, the antibacterial activity dramatically disappeared by $\mathrm{pH}$ change of the $O x a l i s$ extracts. These results indicated that the broad spectrum antibacterial activity in $O$. triangularis is from water soluble, heat-stable substances active only in acidic pH condition. Therefore, the antibacterial substances would be oxalic acid or oxalate compounds which are abundant in Oxalis family plants.
\end{abstract}

Keywords: Antibacterial activity, Oxalis triangularis, Oxalic acid, pH, Food-born pathogen.

Accepted on October 30, 2018

\section{Introduction}

Penicillin was discovered by Sir Alexander Fleming in the study of influenza virus in Staphylococcus aureus by accident that the environment surrounding the blue fungus (Penicillium chrysogenum) in the incubator was aseptic [1]. Hans has developed a special staining method [2] and divided bacteria into two groups which were differed in their cell wall structure later.

Several food-born pathogenic bacteria are well identified [3-9]. Among them Staphylococcus aureus is Gram-positive (+) bacteria and causes serious illness including osteomyelitis, meningitis and neuralgia, vomiting, diarrhea in humans and animals [3]. Staphylococcus aureus is infected mainly via nose and respiratory system caused food poisoning. Other severe food-born Gram $(+)$ bacteria is Bacillus cereus which is large bacilli which arranged in the form of a chain [4]. Because it can cause food poisoning by forming strong spores on heat, it is necessary to sterilize by high temperature. An environment in which the bacterium can grow well and when it is above $10^{6}$ $\mathrm{CFU} / \mathrm{g}$, it causes diarrhea and vomiting. One of the severe food-born Gram-negative (-) bacteria is Salmonella typhimurium which is rod-shaped bacteria and infects mainly in the digestive tract of people and warm-blooded animals causing typhoid fever and enteritis [5]. Recently, problems of pathogenic Escherichia coli have been reported [6]. E. coli discovered in 1885 by Theodore is easily reproduced, genetically comparatively simple and easy to manipulate [7]. Therefore, E. coli is the most studied prokaryotes and is greatly contributed to biotechnological progress. Most E. coli strains are not harmful often seen in the intestines of warm-blooded animals and benefits to the human body for vitamin $\mathrm{K}$ generation [8]. Some pathogenic E. coli cause food poisoning including urethral infection caused by elderly people or patients who have lowered immunity after surgery and traveller's diarrhea [9]. One of the well-studied pathogenic $E$. coli is $E$. coli $\mathrm{O} 157: \mathrm{H} 7$ which produces shiga-like toxins [6].

Oxalis triangularis is a perennial grass native in tropical Mexico and an ornamental plant in purple color which can be decorated for salads or foods. It is resistant to severe environment of high temperature and draught due to bulbous roots [10]. Oxalis corniculata, so called cat eaten plant in Korea, is different in color in green and smaller size compared to $O$. triangularis. The organic compound oxalic acid is isolated by François, Switzerland in 1773 from the wood-sorrel including plant $O$. corniculata and its crystal structure is revealed recently [11]. The oxalic acid is highly acidic which its $\mathrm{pKa}$ is 1.25 and 4.14 because it contains two carboxylate moieties [12]. Some plants such as parsley, chives, purslane, cassava as well as wood-sorrel (oxalis) contain high concentration of oxalic acid over $1 \%$ [13]. The oxalis 
substitution over banana leaves has largely eliminated the food poisoning of bongkrek in Indonesia because the oxalis leaves contribute to decrease of $\mathrm{pH}$ which prevents bacterial overgrowth [14]. The kidney stone is usually caused by calcium oxalate, one of the common oxalate compounds [15]. Color-pigmented plants such as carrot, pepper, paprika etc. harbor rich antioxidants and vitamins which help health to maintain a harmonious diet and a healthy lifestyle.

In this research, from some ethnobotanical evidences of oxalis plants treated in local traditional medicine, antimicrobial activity against various pathogenic bacteria was studied in the extracts of $O$. triangularis in heat-treatment or various $\mathrm{pH}$ value. The antimicrobial substance of $O$. triangularis was not previously suggested to oxalic acid or oxalate compounds which are heat-stable and affected by $\mathrm{pH}$.

\section{Materials and Method}

\section{Plant samples}

The plant samples of pepper, garlic, blueberry, ginseng, paprika, ginger, cinnamon, rosemary and $O$. triangularis were purchased from local market in Jeju, Korea. The $O$. triangularis was grown in the plant growth chamber at $25^{\circ} \mathrm{C}$ with a diurnal cycle of $12 \mathrm{~h}$ light/12 h darkness [16].

\section{Antimicrobial activity in plant extracts}

Eight bacteria $[(S$. aureus (KCTC 1621), B. cereus (KCTC 1021), B. sphaericus (KCTC 1185), S. pyogenes (KCTC 3096), S. mutans (KCTC 3065), E. coli (KCTC 1682), S. typhimurium (KCTC 2057) and E. aerogenes (KCTC 2190)] were ordered from Korean Collection for Type Cultures (KCTC) and inoculated in LB broth (Sigma-Aldrich, Germany) and incubated at $37^{\circ} \mathrm{C}$ for $24 \mathrm{~h}$. The bacteria were spread out on the LB agar (Sigma-Aldrich, Germany) evenly using triangular glass rod sterilized by flame. The plant samples of pepper, garlic, blueberry, ginseng, paprika, $O$. triangularis, ginger, rosemary and cinnamon in a $-80^{\circ} \mathrm{C}$ freezer were crushed and the liquid of supernatant from the crushed samples was extracted after centrifuge at $6,000 \mathrm{rpm}$ for $5 \mathrm{~min}$. The leaves, stems, roots, and buds from $O$. triangularis were divided by blade and the extracts were collected after centrifuge at 6,000 rpm for $5 \mathrm{~min}$. Antibacterial activity of each extract was tested by disk diffusion assay that the extracts were dropped on the bacterial lawn after spreading followed by drying $[17,18]$. Antibiotics such as ampicillin (Sigma-Aldrich, Germany, 25 $\mu \mathrm{g} / \mathrm{ml}$ ) or kanamycin (Sigma-Aldrich, Germany, $25 \mu \mathrm{g} / \mathrm{ml}$ ) were used as positive controls. The diameter of the clear inhibition zone was measured after $24 \mathrm{~h}$ incubation.

\section{Heat treatment for antibacterial substances}

The extracts of mashed $O$. triangularis leaves have been prepared with distilled water and divided in two tubes, and then one tube was heated with boiling water bath at $100^{\circ} \mathrm{C}$ for $1 \mathrm{~min}$ [19]. The antibacterial activity of the heat treated extracts was assayed as the non-treated extract as a control.

\section{Antibacterial assay on neutralization reaction}

The $200 \mu \mathrm{l}$ extracts of $O$. triangularis leaves have been prepared with distilled water and divided into eight tubes, and then added $0 \mu \mathrm{l}, 1 \mu \mathrm{l}, 2 \mu \mathrm{l}, 3 \mu \mathrm{l}, 5 \mu \mathrm{l}, 10 \mu \mathrm{l}$, and $20 \mu \mathrm{l}$ of $10 \mathrm{~N}$ $\mathrm{NaOH}$ solution (Sigma-Aldrich, Germany) to each tube. The $20 \mu \mathrm{l}$ of the $\mathrm{NaOH}$-treated extract was dropped to the medium containing the target bacteria and incubated for $24 \mathrm{~h}$ [19]. The $20 \mu \mathrm{l}$ of a solutions made by mixing $0 \mu \mathrm{l}, 1 \mu \mathrm{l}, 2 \mu \mathrm{l}, 3 \mu \mathrm{l}, 5 \mu \mathrm{l}$, $10 \mu \mathrm{l}$, and $20 \mu \mathrm{l}$ of $10 \mathrm{~N} \mathrm{NaOH}$ and $200 \mu \mathrm{l}$ of water were dropped into each medium cultured by bacteria as negative controls.

\section{Results and Discussion}

The antimicrobial activity was shown in the extracts of garlic and $O$. triangularis among pepper, garlic, blueberry, ginseng, paprika, O. triangularis, ginger, rosemary and cinnamon against E. coli, S. mutans and S. aureus. The antimicrobial activity of $O$. triangularis was further investigated in detail because the activity of garlic is well documented but not in $O$. triangularis [20].

The extracts of $O$. triangularis from leaves showed the broad spectrum antimicrobial activity against Gram $(+)$ bacteria such as $S$. aureus, B. cereus, B. sphaericus, S. pyogenes, S. mutans and Gram (-) bacteria such as E. coli, S. typhimurium, E. aerogenes (Figure 1). It is interesting that the results differ from that of $O$. corniculata which the extracts of $O$. corniculata showed no antibacterial activity against $S$. aureus [21]. However, other report with methanolic extract of $O$. corniculata showed antimicrobial activity against $S$. aureus and various Shigella strains [22]. The extracts of $O$. triangularis from stems, roots, or buds showed the similar antimicrobial activity against Gram (+) and Gram (-) bacteria.

To elucidate the nature of antibacterial substances, the antimicrobial activity was measured after $100^{\circ} \mathrm{C}$ heat treatment or ethanol extraction and compared to the water extraction without heat treatment. The heat-treated extracts of $O$. triangularis leaves showed similar broad spectrum antimicrobial activity and seemed to show stronger antibacterial activity against the target Gram (+) and Gram (-) bacteria compared to that of no heat treatment (Figure 1). It is supposed that the antibacterial substances in the extract were concentrated by the heat treatment due to reduction in total volume and were not in the nature of protein which is easily denaturated by heat. The ethanol extracts of $O$. triangularis leaves showed the similar antimicrobial activity against the target bacteria. It is suggested that the antibacterial substances are dissolved in ethanol as well as water. Therefore, the nature of the antibacterial substances would be assumed to be oxalic acid or oxalate compounds which are abundant in Oxalis family plants [23]. To confirm the hypothesis, the experiment for antibacterial assay using neutralization reaction was designed and performed. The extracts of $O$. triangularis leaves in violet color (acidic $\mathrm{pH}$ ) gradually turned to blue (approx. neutral $\mathrm{pH}$ ) and further to yellow (in basic $\mathrm{pH}$ ) as $\mathrm{NaOH}$ added. It seems that this color change is due to anthocyanins 
abundant in $O$. triangularis [24]. The antibacterial activities in the extracts of $O$. triangularis leaves were showed in the extracts in violet color with the acidity of below $\mathrm{pH} 3.7$. However, the extracts in blue color showed dramatically decreased antibacterial activities against the target Gram $(+)$ and Gram (-) bacteria (Figure 2). The antibacterial activities were re-appeared in the extracts in yellow color. The fact that the antibacterial activity comes from the nature of $\mathrm{NaOH}$ added was confirmed from the control experiment which the activity was measured in the water added different volume of $\mathrm{NaOH}$.

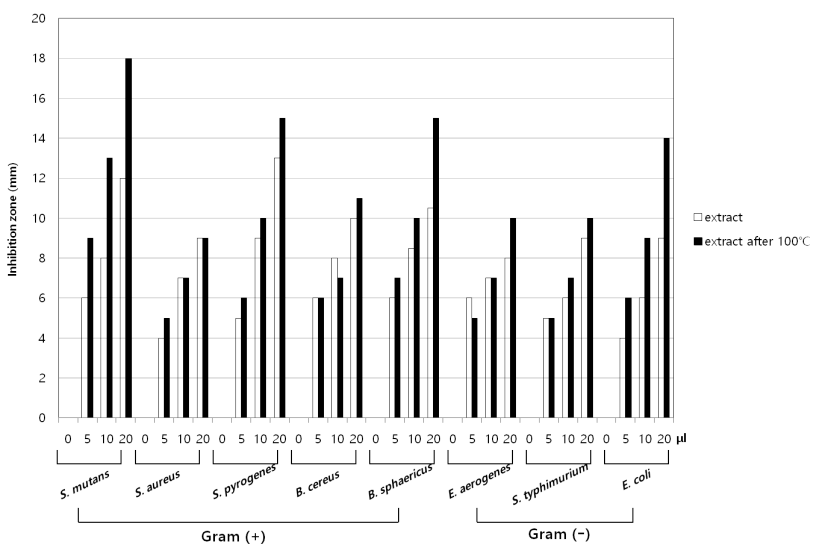

Figure 1. Antibacterial activity in the water extracts of Oxalis leaves after heat treatment. The diameter $(\mathrm{mm})$ of the inhibition zone was graphed in the extracts (open square) and the extracts after $100^{\circ} \mathrm{C}$ treatment (closed square) over the extracts added ( $\mu l$ ).

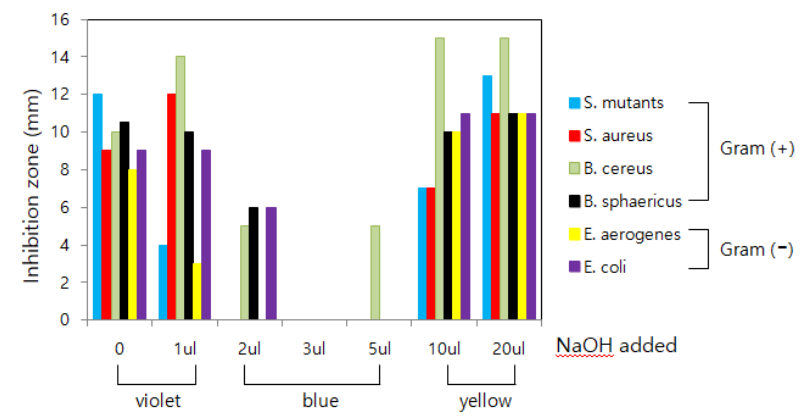

Figure 2. Antibacterial activity of Oxalis extracts on neutralization reaction. The color of $\mathrm{O}$. triangularis extracts by $\mathrm{NaOH}$ addition was designated on the $x$-axis. The target bacteria are shown in colors in $S$. mutans (blue), S. aureus (red), B. cereus (green), B. sphaericus (black), E. aerogenes (yellow) and E. coli (violet), respectively.

These results indicated that the extracts of $O$. triangularis show broad spectrum antibacterial activity in acidic $\mathrm{pH}$. The further experiment with pure oxalic acid was performed to confirm the hypothesis that the substances of the antibacterial activity would be oxalic acid or oxalate compounds. The antibacterial activity was shown in the concentration of pure oxalic acid with above $71 \mathrm{mM}$.

It is not excluded that other biologically active compounds in bactericidal activity rather than oxalic acid may be existed in the extracts of $O$. triangularis plants. The previous report revealed that the isolated antibacterial substances in the extracts of $O$. corniculata were 5-hydroxy-6, 7, 8, 4tetramethoxyflavone and 5, 7, 4'-trihydroxy-6, 8dimethoxyflavone [21]. It could be predicted that the concentration and $\mathrm{pH}$ effects by oxalic acid or oxalate salts would be affected to other biological activities such as antifungal or insecticidal effects [21]. The other viewpoint in the plant physiology is how the Oxalis plant cells maintain and resist in such a strong acidity. Based on the discovery of the natural antimicrobial effect derived from plants against both Gram (+) and Gram (-) bacteria, it can be used for prevention and treatment of various food poisoning, tooth decay or livestock or crop diseases caused by pathogenic bacteria, It is also applied to reduction of odor in piggery, barn or henhouse.

\section{Acknowledgement}

We would like to thanks Korean Collection for Type Cultures (KCTC) for providing bacterial stains. This study was supported by Science focused school program from Korea foundation for the advancement of science and creativity and Ministry of education, Republic of Korea. We thanks to SooJin Kang of Namnyeong High School and Bang-Ja Ko, Yun-Ji Kang and Soo-Bin Yang of Hyodon Middle School for her helpful support and comments. We are grateful to Sustainable Agriculture Research Institute (SARI) in Jeju National University for providing the experimental facilities.

\section{References}

1. Clutterbuck PW, Lovell R, Raistrick H. Studies in the biochemistry of micro-organisms: the formation from glucose by members of the Penicillium chrysogenum series of a pigment, an alkali-soluble protein and penicillin-the antibacterial substance of Fleming. Biochem J 1932; 26: 1907-1918.

2. Ollett WS. A method for staining both gram-positive and gram-negative bacteria in sections. J Pathol Bacteriol 1947; 59: 357.

3. Mayberry-Carson KJ, Tober-Meyer B, Smith JK, Lambe DW Jr, Costerton JW. Bacterial adherence and glycocalyx formation in osteomyelitis experimentally induced with Staphylococcus aureus. Infect Immun 1984; 43: 825-833.

4. Stuy JH. Studies on the mechanism of radiation inactivation of micro-organism. II. Photoreactivation of some bacilli and of the spores of two Bacillus cereus strains. Biochim Biophys Acta 1956; 22: 238-240.

5. Buckner MM, Croxen MA, Arena ET, Finlay BB. A comprehensive study of the contribution of Salmonella enterica serovar Typhimurium SPI2 effectors to bacterial colonization, survival, and replication in typhoid fever, macrophage, and epithelial cell infection models. Virulence 2011; 2: 208-216.

6. OBrien AD, Lively TA, Chang TW, Gorbach SL. Purification of Shigella dysenteriae 1 (Shiga)-like toxin from Escherichia coli O157: H7 strain associated with haemorrhagic colitis. Lancet 1983; 2: 573. 
7. Shulman ST, Friedmann HC, Sims RH. Theodor Escherich: the first pediatric infectious diseases physician? Clin Infect Dis 2007; 45: 1025-1029.

8. Cox GB, Gibson F. Biosynthesis of vitamin $\mathrm{K}$ and ubiquinone. Relation to the shikimic acid pathway in Escherichia coli. Biochim Biophys Acta 1964; 93: 204-206.

9. Feldman M. Travelers diarrhea. Am J Med Sci 1984; 288: 136-148.

10. Oberlander KC, Emshwiller E, Bellstedt DU, Dreyer LL. A model of bulb evolution in the eudicot genus Oxalis (Oxalidaceae). Mol Phylogenet Evol 2009; 51: 54-63.

11. Diallo W, Gueye N, Crochet A, Plasseraud L, Cattey H. Crystal structure of di-methyl-ammonium hydrogen oxalate hemi (oxalic acid). Acta Crystallogr E Crystallogr Commun 2015; 71: 473-475.

12. Bjerrum J, Schwarzenbach G, Sillen LG. Stability constants. Chemical Society London 1958.

13. USDA. Vegetables and vegetable products, Agriculture Handbook Washington D.C. 1984; 8-11.

14. Taylor SL, Hefle SL. Foodborne diseases (3rd Ed.). Elsevier Inc. 2017.

15. Lund T, Reske-Nielsen E. Nephrolithiasis and nephrocalcinosis with calcium oxalate crystals in the kidneys and other organs; report of two cases. Acta Pathol Microbiol Scand 1956; 38: 353-363.

16. Kim JS, Lee M, Chalam R, Martin MN, Leustek T, Boerjan W. Constitutive overexpression of cystathionine $\gamma$-synthase in Arabidopsis leads to accumulation of soluble methionine and S-methylmethionine. Plant Physiol 2002; 128: 95-107.

17. Raahave D. Paper disk-agar diffusion assay of penicillin in the presence of streptomycin. Antimicrob Agents Chemother 1974; 6: 603-605.

18. Khan AM, Qureshi RA, Gillani SA, Ullah F. Antimicrobial activity of selected medicinal plants of
Margalla hills, Islamabad, Pakistan. J Medic Plant Res 2011; 5: 4665-4670.

19. Ogunbanwo ST, Sanni A, Onilude AA. Characterization of bacteriocin produced by Lactobacillus plantarum $\mathrm{F}$ and Lactobacillus brevis OG. Afr J Biotechnol 2003; 2: 219-227.

20. Goncagul G, Ayaz E. Antimicrobial effect of garlic (Allium sativum). Recent Pat Antiinfect Drug Discov 2010; 5: 91-93.

21. Rehman A, Rehman A, Ahmad I. Antibacterial, antifungal, and insecticidal potentials of Oxalis corniculata and its isolated compounds. Int J Anal Chem 2015; 1: 1-5.

22. Mukherjee S, Koley H, Barman S, Mitra S, Datta S, Ghosh S, Paul D, Dhar P. Oxalis corniculata (Oxalidaceae) leaf extract exerts in vitro antimicrobial and in vivo anti-colonizing activities against Shigella dysenteriae 1 (NT4907) and Shigella flexneri 2a (2457T) in induced diarrhea in suckling mice. J Med Food 2013; 16: 801-809.

23. Ross AB, Savage GP, Martin RJ, Vanhanen L. Oxalates in oca (New Zealand yam) (Oxalis tuberosa Mol.). J Agric Food Chem 1999; 47: 5019-5022.

24. Fossen T, Rayyan S, Holmberg MH, Nateland HS, Andersen ŘM. Acylated anthocyanins from leaves of Oxalis triangularis. Phytochemistry 2005; 66: 1133-1140.

\section{${ }^{*}$ Correspondence to}

Jung-Sup Kim

Faculty of Biotechnology

SARI

Jeju National University

Republic of Korea 